\title{
Cu添加低合金鋼の機械的特性に及ぼす 二相域焼入れの影響
}

\author{
本間 祐太 ${ }^{1) *} \cdot$ 橋 邦彦 $^{1)} \cdot$ 佐々木 元 $^{1)} \cdot$ 大川 环哉 ${ }^{1)} \cdot$ 長井 寿 $^{21}$
}

Effect of Intercritical Quenching on Mechanical Properties of Cu-containing Low Alloy Steel

Yuta Honma, Kunihiko Hashi, Gen Sasaki, Takuya OKawa and Kotobu Nagai

Synopsis : Better balance of strength and toughness is a strong demand for the ASTM A707 L5 grade steel. In the present study, therefore, the combination of hardening by $\mathrm{Cu}$ precipitates and toughening by quenching from a dual-phase $(\alpha+\gamma)$ region, so-called intercritical quenching or lamellarizing, has been investigated for a better balance of strength and toughness. The combination procedure resulted in a drastic increase in toughness at low temperatures with a slight decrease in yield strength.

The lamellarizing brought about a complicated microstructure with meandered high angle grain boundaries (HAGB) and fine grains bordered by the HAGB. The final microstructure was composed of granular bainitic ferrites without retained $\gamma$ and basically dual of a softer phase and a harder phase. The softer phase inherited the not-transformed $\alpha$ phase region in lamellarizing and contained coarse $\mathrm{Cu}$ precipitates. The harder phase inherited the transformed $\gamma$ phase region in lamellarizing and contained no $\mathrm{Cu}$ precipitates. Hence, over-aging of $\mathrm{Cu}$ precipitation in the softer phase might result in the slight decrease in yield strength.

In the present steel, the retained $\gamma$ has nothing to do with the improved toughness. Hence, the effective grain size $\left(d_{\mathrm{EFF}}\right)$ approach was verified to account for the microstructural effect on toughness. The unit microstructure to determine the $d_{\mathrm{EFF}}$ was identified to be the bainitic ferrite grain bordered by the HAGB. The refinement of the $d_{\mathrm{EFF}}$ through lamellarizing can be attributed to the improved toughness.

Key words : Cu containing low alloy steel; ASTM A707; intercritical quenching; lamellarizing; mechanical property; effective grain size.

\section{1. 緒言}

石油・天然ガスはエネルギーの中心として，世界の一次 エネルギーの約6割を占めており，世界人口と新興国のエ ネルギー消費量の増加とともに, 今後も石油・天然ガスの 需要は増加傾向と予想されている。これらの開発は陸地か ら海洋へ移行し, 近年の海洋資源開発は大陸棚より大水深 でTension Leg Platform (TLP) やFloating Production, Storage and Offloading System（FPSO）を利用した採掘が主流にな りつつある。さらに最近では $5000 \mathrm{ft}$ (約 $1500 \mathrm{~m})$ 以深の超 大深水の開発に向けた取り組及が行わ机ている ${ }^{1}$ 。一方, 一度海洋事故が発生すると, 周辺環境に与える悪影響が 甚大であるため, 極地, 大水深に打ける気象・海象条件が 厳しい開発エリアでは, 掘削リグや生産プラットフォー ムの設計基準は高いレベルとなっている。それにともな い, 海水中での引張一圧縮荷重下で使用される海洋構造 物用厚肉鍛鋼部材には, 安全性確保の観点から, 落重試験 (Drop Weight Test：DWT) やき裂先端開口変位 (Crack Tip Opening Displacement:CTOD) 試験など, 材料のアレスト性,
破壊靶性に対する評価およびその要求値も厳しくなってき ている。

これら海洋構造物用鋼の多くは, 溶接されて組み立てら れることから, 溶接性の確保のために, 低い炭素当量 $\left(\mathrm{C}_{\mathrm{eq}}\right)$ と溶接割れ感受性組成 $\left(\mathrm{P}_{\mathrm{cm}}\right)$ が要求される。一方で, 部材 の軽量化を目的に高強度化が志向されることから, 低Cで かつ析出硬化元素であるCuを含有する低合金鋼 (ASTM A707 Grade L5の改良鋼) が広く適用されている2)。A707 Gr. L5 改良鋼は，通常の調質熱処理（焼入れ一焼戻し）によ り, $80 \mathrm{ksi}$ 級 $(0.2 \% \mathrm{Y} . \mathrm{S} . \geqq 552 \mathrm{MPa})$ の強度の比較的安定的 な確保は可能であるが, 昨今の海洋構造物用鋼に要求され ている高い破壊勒性に対しては安定的な確保が困難であ る。

そこで, 二相域焼入れ (Lamellarizing:L) 処理に着目した。 $\mathrm{L}$ 处理は, $\mathrm{A}_{\mathrm{C} 3}$ 点以上の保持温度 ( $\gamma$ 相単相) から焼入れを実 施する通常の焼入れ処理とは異なり, $\mathrm{A}_{\mathrm{C} 1}$ 点と $\mathrm{A}_{\mathrm{C} 3}$ 点の間の $\alpha$ と $\gamma$ 相からなる二相域温度で保持した後, 焼入れを実施 する熱処理方法である。L処理の適用事例は, $780 \mathrm{MPa}$ 級建 築用鋼の高強度一低降伏比 (Yield Ratio：YR) 化 ${ }^{3)}$, および

平成29年2月10日受付 平成29年6月5日受理 (Received on Feb. 10, 2017 ; Accepted on Jun. 5, 2017)

1）（株）日本製鋼所室蘭研究所（Muroran Research Laboratory, The Japan Steel Works, Ltd., 4 Chatsu-machi Muroran Hokkaido 051-8505)

2) 物質 - 材料研究機構 (National Institute for Materials Science)

* Corresponding author : E-mail : yuta_honma@jsw.co.jp

DOI : http://dx.doi.org/10.2355/tetsutohagane.TETSU-2017-006 
$9 \% \mathrm{Ni}$ 鋼などの極低温用鋼の低温靶性の確保 ${ }^{4)}$ などがある。 前者については, 二相域加熱中に $\alpha$ 相から逆変態した $\gamma$ 相 が，その後の焼入れによりフレッシュマルテンサイト，即 ち硬質相となることで引張強度 (T.S.) を担保し, 未逆変態 の $\alpha$ 相は高温焼戻しを受けて軟質相となり, 降伏強さが低 下することで，低YR化を実現している ${ }^{3)}$ 。また，後者につ いては，二相域加熱中に $\alpha$ 相から逆変態した $\gamma$ 相に $\mathrm{Ni}$ など の $\gamma$ 安定化元素が濃化し，低温まで安定に存在できるよう になった $\gamma$ 相が残留，分散することが主要因であると報告 されている4)。

しかし, 低Cで, かつ $\mathrm{Cu}$ 粒子により析出強化される海洋 構造物用鋼においては, 機械的特性に及ぼすL処理の影響 を調査した研究は少ない。そこで本研究では, 代表的な海 洋構造物用鋼であるASTM A707 Gr. L5 改良鋼を対象に, 機 械的特性に及ぼす二相域焼入れの影響を明確にすることを 目的とした。また, 組織や析出物の詳細観察を実施し, 機 械的特性発現機構についても検討した。

\section{2. 実験方法}

供試材は真空誘導溶解 (Vacuum Induction Melting：VIM) で溶製したASTM A707 Gr. L5 改良鋼の $50 \mathrm{~kg}$ 小型試験鋼塊 を初期加熱温度 $1523 \mathrm{~K}$ で鍛造したものである。Table 1 に 供試材の化学組成を示す。本鋼種は, 調質熱処理時の焼入 れ性と溶接性確保のために, 低Cかつ Niを約 $2.0 \mathrm{mass} \%$, 調質後の強度確保および耐食性向上の観点から, Cuを約 $1.2 \mathrm{mass} \%$, 調質の結晶粒微細化を達成するために, Alを 含有することが特徵である。なお, 本鋼種の連続加熱時 の変態点も同表に示しているが, $\mathrm{A}_{\mathrm{C} 1}$ 点が $927 \mathrm{~K}, \mathrm{~A}_{\mathrm{C} 3}$ 点が $1081 \mathrm{~K}$ である。なお, $\mathrm{A}_{\mathrm{C} 1}$ および $\mathrm{A}_{\mathrm{C} 3}$ 点の測定は $\phi 3 \mathrm{~mm}$, $L 10 \mathrm{~mm}$ の試料を用いて, 変態点測定装置 (富士電波工機 Formastor-EDP) にて実施した。本実験では，この供試材を 用いて機械的特性に及ぼす L 処理の影響を調査した。

Fig.1 に熱処理条件を示す。1233 Kで焼準 (Normalizing : $\mathrm{N})$ 後, $1173 \mathrm{~K}$ から肉厚 $300 \mathrm{~mm}$ 製品の中心部相当の水冷の 冷却速度を模したシミュレーション冷却 (Quenching : Q) を実施した。なお, 大型肉厚製品では, 水冷でも冷却速度 が小さいため, 本鋼の場合マルテンサイトではなくべイナ イト組織となる。Q後に873 Kで焼戻し（Tempering：T）を

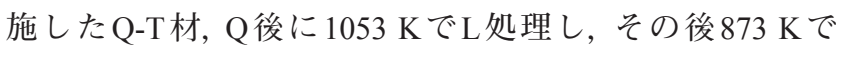
焼戻したQ-L-T材を準備した。

Table 1. Chemical composition (mass\%) and transformation temperature $(\mathrm{K})$ of the steel investigated.

\begin{tabular}{cccccccc|cc|}
\hline \multicolumn{1}{c|}{ Chemical composition (mass\%) } & \multicolumn{2}{c}{$\begin{array}{c}\text { Transformation } \\
\text { temp. (K) }\end{array}$} \\
\hline $\mathrm{C}$ & $\mathrm{Si}$ & $\mathrm{Mn}$ & $\mathrm{Ni}$ & $\mathrm{Cr}$ & $\mathrm{Cu}$ & $\mathrm{Mo}$ & Other & $\mathrm{A}_{\mathrm{C} 1}$ & $\mathrm{~A}_{\mathrm{C} 3}$ \\
\hline 0.03 & 0.35 & 1.40 & 2.15 & 0.72 & 1.27 & 0.46 & $\mathrm{Al}, \mathrm{Nb}$ & 927 & 1081 \\
\hline
\end{tabular}

ミクロ組織観察は, $2 \%$ 硝酸アルコール $(2 \%$ ナイタール $)$ にてエッチングを施し, 光学顕微鏡により行った。旧 $\gamma$ 粒 の結晶粒度は, 界面活性剤を加えた飽和ピクリン酸水溶液 に浸漬させた後，5\%ピクリン酸アルコール／ピロ亜硫酸 ナトリウム水溶液の混合液に浸漬させることで得た旧 $\gamma$ 粒 界組織を画像解析から求めた。それぞれの旧 $\gamma$ 粒径を円相 当径に換算し, 最大值, 平均值および粒径分布から旧 $\gamma$ 粒 径を評価した。

材料特性評価としては, 引張試験, シャルピー衝撃試 験およびCTOD試験を実施した。引張試験は標点間距離 (G.L.) $50 \mathrm{~mm}$, 直径 $\phi 12.5 \mathrm{~mm}$ (JIS Z2201 10 号試験片) の 平滑丸棒引張試験片を用いて室温で実施した。

シャルピー衝撃試験は $2 \mathrm{mmV}$ ノッチ試験片 (JIS Z2242) を用い, 試験温度 133〜273 K で実施し，延性破面率が 50\% となる延性一脆性遷移温度 (Fracture Appearance Transition Temperature : FATT) を求めた。また, 有効結晶粒径 $\left(d_{\mathrm{EFF}}\right)$ に及ぼすL処理の影響を明確にするために，シャルピー 衝撃試験後の脆性破面 (へき開破面) を走査型電子顕微鏡 (Scanning Electron Microscope : SEM, JEOL JSM-6060A) に て観察し, 画像解析から求めたそれぞれのへき開破面の大 きさ(破面単位) を円相当径に換算し，それらを $d_{\mathrm{EFF}}$ とした。 最大值，平均值および粒径分布から $d_{\mathrm{EFF}}$ を評価した。なお， 各種 $d_{\mathrm{EFF}}$ の平均サイズは全ての割合で重み付けした加重平 均值を用いた。

CTOD試験から得られる破壊靶性特性 (CTOD值) は試 験片寸法によって異なることが言われている。そこで本 研究では, 薄型試験片と厚型試験片の2 種類の試験材を用 いて評価を実施した。各試験片形状を Fig.2 に示す。薄型 試験片として試験片板厚 (B) が 16.7 または $17.1 \mathrm{~mm}$, 高さ (2B) のB $\times 2 \mathrm{~B}$ 試験片を用いた。また, 厚型試験片として 試験片板厚 (B) が 80 または $100 \mathrm{~mm}$, 高さ $(\mathrm{B})$ の $\mathrm{B} \times \mathrm{B}$ 試 験片を用いた。試験温度は, 薄型試験片では $253 \mathrm{~K}$, 厚型試

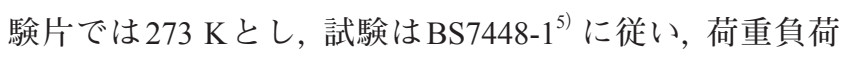

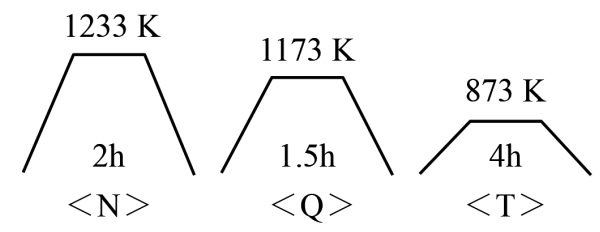

(a) Q-T

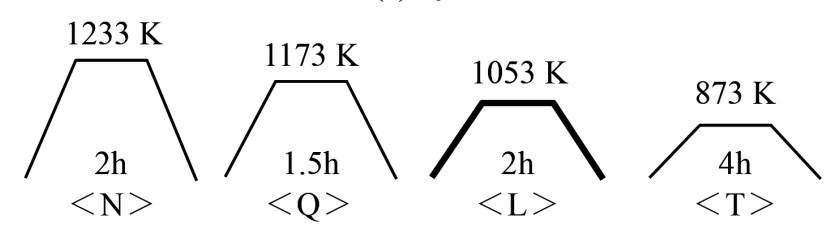

(b) Q-L-T

Fig. 1. Heat treatment condition producing Q-T (a) and Q-L-T (b) materials. 
速度 $(d K / d t)$ は $0.5 \sim 3.0 \mathrm{MPa} \cdot \mathrm{m}^{1 / 2} / \mathrm{s}$ の範囲で実施した。得 られたクリップゲージ開口量と荷重から，式（1）を用いて CTOD值 $(\delta)$ を算出した ${ }^{6)}$ 。

$$
\delta=\frac{K^{2}\left(1-v^{2}\right)}{2 \sigma_{Y} E}+\frac{r_{p}\left(W-a_{0}\right) V_{p}}{r_{p}\left(W-a_{0}\right)+a_{0}+z}
$$

ここで, $\delta$ はき裂先端開口変位 $(\mathrm{mm}), K$ は応力拡大係数 $\left(\mathrm{MPa} \cdot \mathrm{m}^{1 / 2}\right), E$ はヤング率, $v$ はポアソン比, $r_{p}$ はローテー ションファクター $\left(a_{0} / W=0.5\right.$ の場合, $\left.r_{p}=0.4\right), W$ は試験 片幅 $(\mathrm{mm}), a_{0}$ は初期き裂長さ $(\mathrm{mm}), V_{p}$ は切欠き末端開口 変位の塑性成分 $(\mathrm{mm}), z$ はナイフエッジ高さ $(\mathrm{mm})$ である。

$\mathrm{L}$ 処理時の組織形成挙動の把握は, 機械的特性発現入力 ニズムを推定するために必要な情報であり, 特に L 処理 温度での $\alpha \rightarrow \gamma$ 逆変態挙動を把握する必要がある。そこで 本研究では, 高温加熱および保持中にin-situで測定可能な 加熱ホルダーを用い, サーマル型電解放射型走査型電子 顕微鏡 (Field Emission Scanning Electron Microscope : FESEM, JEOL JSM-7100F) に取り付けた電子線後方散乱分光 (Electron Back Scatter Diffraction：EBSD) 装置 (TSL MSC2200）にて, L処理時の逆変態挙動の高温EBSD測定を実施 した。供試材はQまま材 $(1173 \mathrm{~K})$ を用い, Fig.3に示すよ うに, $\mathrm{A}_{\mathrm{C} 1}$ 点以下の温度から $\mathrm{A}_{\mathrm{C} 3}$ 点以上の温度範囲にて, 任

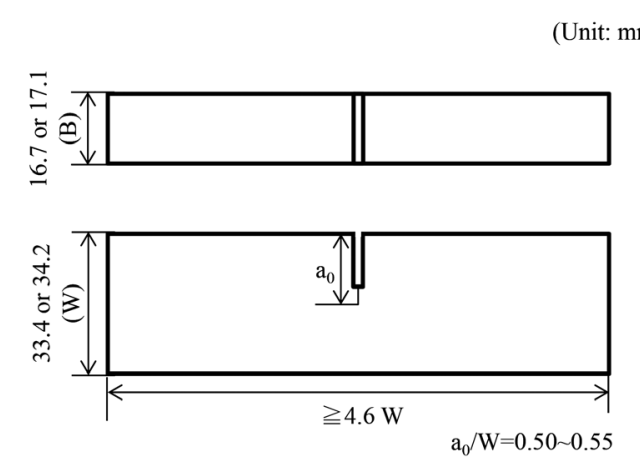

(a) Thin type $(\mathrm{B} \times 2 \mathrm{~B})$
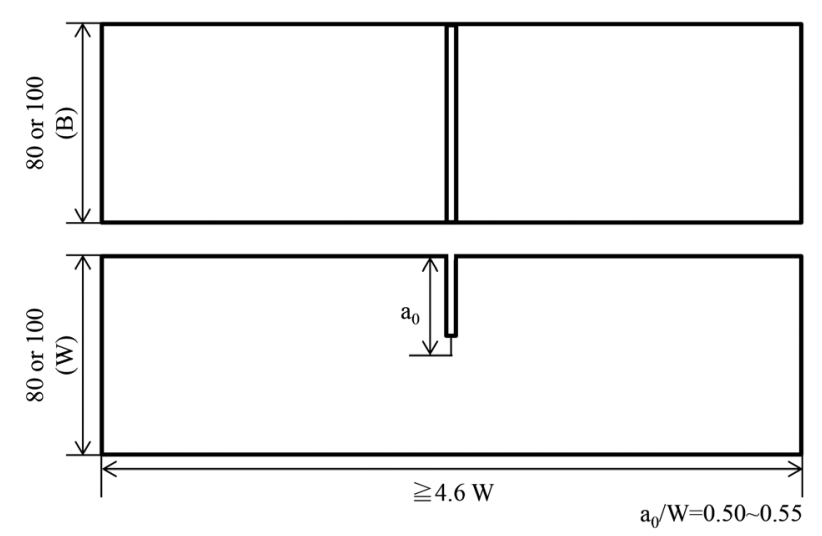

(b)Thick type $(\mathrm{B} \times \mathrm{B})$

Fig. 2. CTOD specimen sizes of thin type (a) and thick type (b) (3 point bending type).
意の温度で, 相変態の様子を観察した。各測定位置はおお よそ同位置とし， $\alpha \rightarrow \gamma$ 逆変態挙動をPhase mapを用いて評 価した。

析出物観察は透過型電子顕微鏡 (Transmission Electron Microscope：TEM）にて評価した。L処理中の析出物（特に $\mathrm{Cu}$ 析出物) の分散状態を把握するため, L 処理温度 $1053 \mathrm{~K}$ で $2 \mathrm{~h}$ 保持した後, 組織凍結のため室温まで水冷した試料 の薄膜を用い, 逆変態 $\gamma$ および未逆変態 $\alpha$ 中の析出物を観 察した。

さらに， $d_{\mathrm{EFF}}$ を支配する金属組織を特定するため, EBSD を用いて, シャルピー衝撃試験後の脆性破壊の起点部近傍 の断面に観察されるサブクラック周辺の結晶方位解析を実 施した。加えて, 結晶方位差 $15^{\circ}$ 以上の大角境界で囲まれ た粒径 (以下, ベイニティックフェライト粒径と定義する) を求めた。1視野あたりの測定範囲は $80 \times 200 \mu \mathrm{m}$, 視野数 5 とし, それらの集計結果から最大, 平均值および粒径分 布について評価した。なお, ベイニティックフェライト粒 径の平均值も加重平均值を用いた。

\section{3. 実験結果および考察}

\section{$3 \cdot 1$ 機械的特性に及ぼす $L$ 処理の影響}

Q-T材およびQ-L-T材のミクロ組織の光学顕微鏡像を Fig.4に, 旧 $\gamma$ 粒観察結果を Fig. 5 に示す。まず，ミクロ組織 についてであるが, Araki らの分類 ${ }^{7,8)}$ によると, グラニュ ラーベイニティックフェライト $\left(\alpha_{\mathrm{B}}\right)$ およびベイニティッ クフェライト $\left(\alpha_{\mathrm{B}}^{\circ}\right)$ が上部ベイナイトとして定義されてい るが，それらは低炭素鋼特有の形状の違いによって区別さ れている。 $\alpha_{\mathrm{B}}$ は塊状のベイニティックフェライトであり， 転位下部組織は存在するものの, 回復がかなり進行してお り，ラスの形状が不明瞭であると言われている。一方で, $\alpha_{\mathrm{B}}^{\circ}$ はラス状のべイニティックフェライトで, 低炭素鋼の場 合は，内部に炭化物を含まず，旧 $\gamma$ 粒界が保存されている と言われている。これらの分類判別を基に, 本鋼種の組織 が塊状であること, 旧 $\gamma$ 粒界がやや不鮮明であることなど を考慮すると, Q-T材, Q-L-T材ともにミクロ組織は $\alpha_{\mathrm{B}}$ と 判断された。L処理によって生成した逆変態 $\gamma も$, 本実験 条件の冷却速度（肉厚 $300 \mathrm{~mm}$ 製品の中心部相当）では，マ

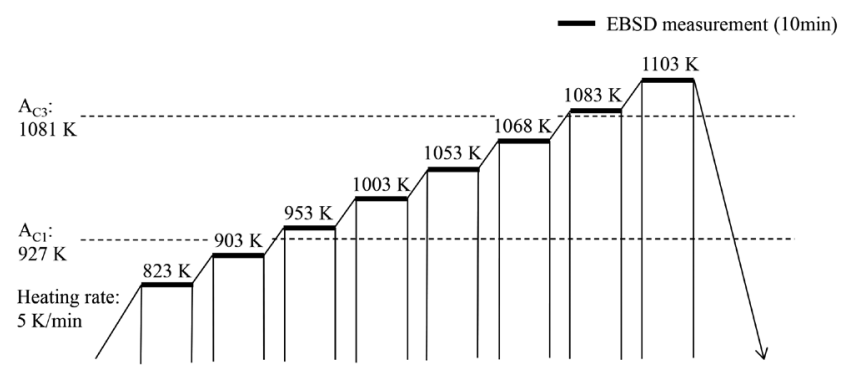

Fig. 3. In-situ EBSD measurement condition. 
ルテンサイト変態しなかった。また，L処理後であっても， 残留 $\gamma$ は認められなかった。一方で, 組織の様相は若干異 なり, L処理を適用したQ-L-T材の方が, やや複雑な様相 を示した。この複雑さについてはEBSD測定結果にて記述 する。また，旧 $\gamma$ 粒径測定結果は, Q-T材では平均旧 $\gamma$ 粒径 $24.0 \mu \mathrm{m}$ に対し, Q-L-T材では平均旧 $\gamma$ 粒径 $15.7 \mu \mathrm{m}$ となり, Q-L-T材が微細な結果となった。

室温引張試験結果を Table 2 に示す。Q-T材では $0.2 \% \mathrm{Y}$. S.が $640 \mathrm{MPa}$, T.S. が $729 \mathrm{MPa}$ であったのに対し, Q-L-T材 では $0.2 \%$ Y.S. が $569 \mathrm{MPa}$, T.S.が $726 \mathrm{MPa}$ となり, L処理に より $0.2 \%$ Y.S.のみが低下し，結果的にYRの低下が認めら れた。本鋼種のような $\mathrm{Cu}$ 添加鋼においても, 高強度建築用 鋼などと同様の傾向 ${ }^{3)}$ が示された。

シャルピー衝撃試験より得られた遷移曲線（衝撃吸収工 ネルギー, 延性破面率) をFig.6に示す。いずれの熱処理条 件であっても，上部棚エネルギーはほぼ同等と考えられ， 約 270 Jであった。FATTはQ-T材で 233 K, Q-L-T材で 193 Kとなり，L処理によって FATTが約 $70 \mathrm{~K}$ 低下した。また, これらの結果から Q-L-T材は, 非常に優れた低温勒性を有 していることが確認された。

Table 2. Tensile properties of the Q-T and Q-L-T materials.

\begin{tabular}{cccccc}
\hline & YS (MPa) & TS (MPa) & El. (\%) & RA (\%) & YR (-) \\
\hline Q-T & 640 & 729 & 28 & 76 & 0.88 \\
\hline Q-L-T & 569 & 726 & 27 & 75 & 0.78
\end{tabular}

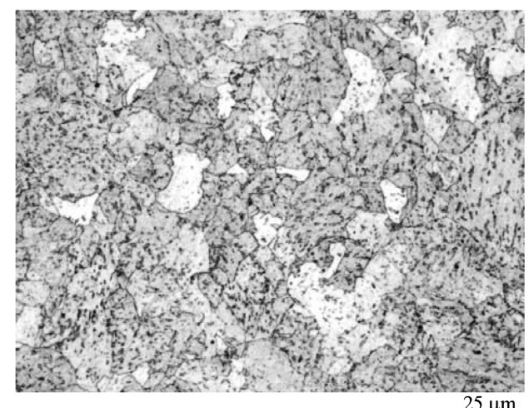

(a) Q-T
Q-T材，Q-L-T材ともに脆性破面が主体（下部棚）とな る試験温度で破断させたシャルピー衝撃試験片を用い, 起 点部近傍の破面のSEM観察を実施した。SEM像を Fig.7に 示す。破面はいずれもリバーパターンを示すへき開破面と なっており, 粗大なセメンタイトや介在物などは認められ

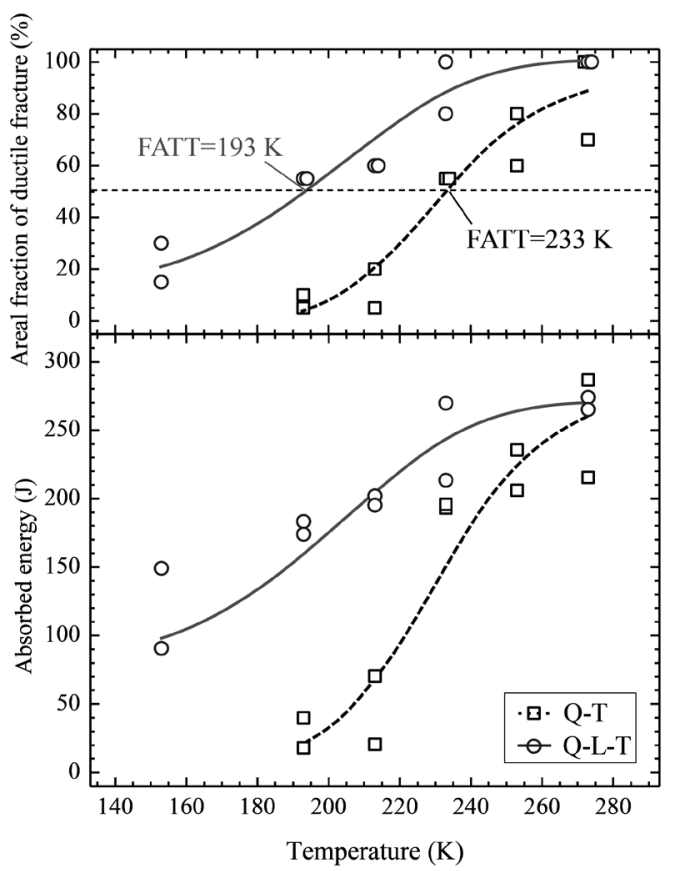

Fig. 6. Transition curves of absorbed energy (bottom) and areal fraction of ductile fracture (top) in Charpy impact test for Q-T and Q-L-T materials.

Fig. 4. Optical images of microstructure for Q-T (a) and Q-L-T (b) materials.

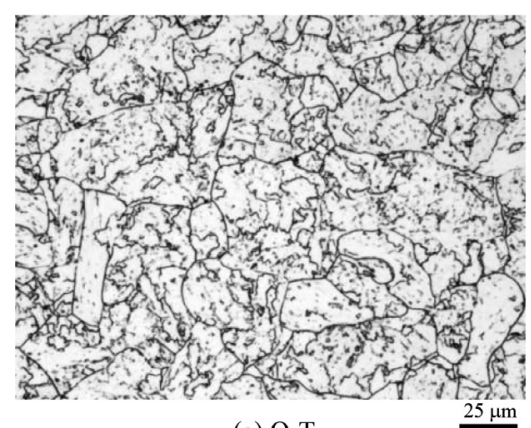

(a) Q-T

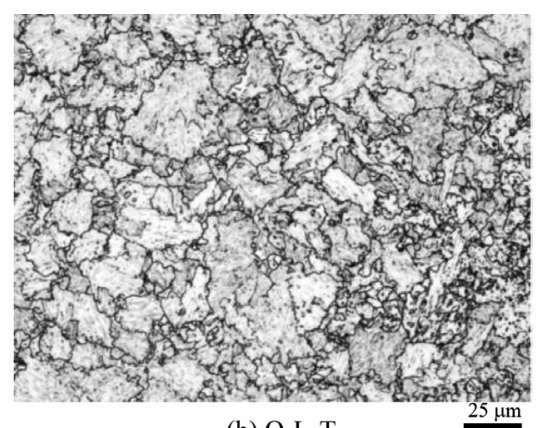

(b) Q-L-T

Fig. 5. Prior austenite grain boundary image of Q-T (a) and Q-L-T (b) materials. 
なかった。これより，いずれの供試材も脆性破面形態は粒 内へき開破壊であると判断され，L処理による脆性破面形 態の変化は認められなかった。

一般に $d_{\mathrm{EFF}}$ が小さいほど勒性が向上する,10) ことから, この破面の SEM像から $d_{\mathrm{FFF}}$ を求めた。なお, $d_{\mathrm{EFF}}$ はFig.7に 示したように, へき開破面の一単位 (破面単位) を円相当 径に換算したものである。 $d_{\mathrm{EFF}}$ の分布を Fig.8に示す。Q-T 材では最大で $41.5 \mu \mathrm{m}$, 平均で $12.0 \mu \mathrm{m}$ であったのに対し, Q-L-T材では最大で $31.7 \mu \mathrm{m}$ ，平均で $8.0 \mu \mathrm{m}$ となった。ま た，その分布ピークはQ-L-T材では細粒側に移行した。し たがって，L処理での $d_{\mathrm{EFF}}$ の微細化が，FATTを低温側にシ フトさせた一つの要因として考えられる。また, $d_{\mathrm{EFF}}$ を支 配する組織因子については, EBSD測定による組織詳細観 察結果で後述する。

Table 3 に薄型CTOD試験結果 (試験温度 $253 \mathrm{~K}$ ) を, Table 4 に厚型CTOD試験結果（試験温度 $273 \mathrm{~K}$ ) を示す。表中の $\delta_{\mathrm{c}}$ は安定き裂長さが $0.2 \mathrm{~mm}$ 以下で不安定き裂進展が生じ た際のCTOD值， $\delta_{u}$ は安定き裂長さが $0.2 \mathrm{~mm}$ 以上で，かつ 最大荷重点前に不安定き裂進展が生じた際のCTOD值, $\delta_{\mathrm{m}}$ は最大荷重点でのCTOD值を示す。薄型CTOD試験結果よ り，Q-T材では3本中2本は不安定破壊が生じることなく 最大荷重点まで到達 $\left(\delta_{\mathrm{m}}\right)$ したが, 残りの1本はほぼ安定き 裂が発生することなく, 不安定き裂進展が生じ $\left(\delta_{\mathrm{c}}: 0.09\right.$ $\mathrm{mm})$, 安定的な CTOD特性が得られなかった。一方, Q-L-T 材は3本中 3 本で最大荷重点まで到達 $\left(\delta_{\mathrm{m}}\right)$ し, L 処理によ

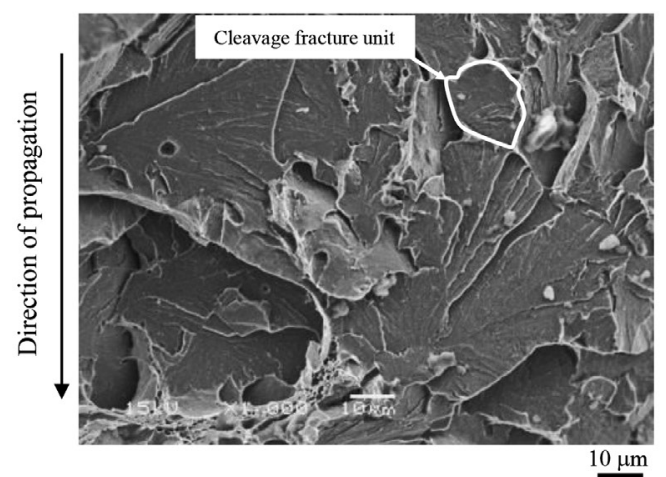

(a) Q-T
り安定的にCTOD值が得られた。また, 厚型CTOD試験で はQ-T材 (試験片板厚 : $80 \mathrm{~mm}$ ) とQ-L-T材 (試験片板厚 : $100 \mathrm{~mm}$ ) で試験片形状が異なるが，いずれも実験值の妥当 性が保たれる板厚であるため, CTOD值を比較した。Q-T 材では2本中 2 本で最大荷重点到達前に $\left(\delta_{\mathrm{u}}\right)$ 不安定破壞 が生じたのに対し, Q-L-T材では2本中 2本で最大荷重点 $\left(\delta_{\mathrm{m}}\right)$ まで到達した。本試験結果から得られた試験片板厚と CTOD值の相関を Fig.9に示すが，特に厚型CTOD試験片を 用いた場合において，L処理による顕著な CTOD特性の向 上が認められた。不安定破壞の発生は, 板厚の増加に伴う 塑性拘束の増大によるき裂端の引張応力の最大值の増加

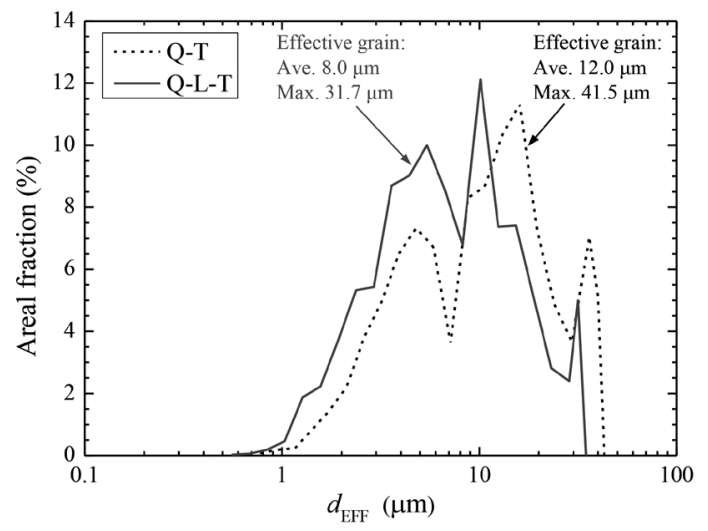

Fig. 8. Histogram of effective grain size for Q-T and Q-L-T materials.

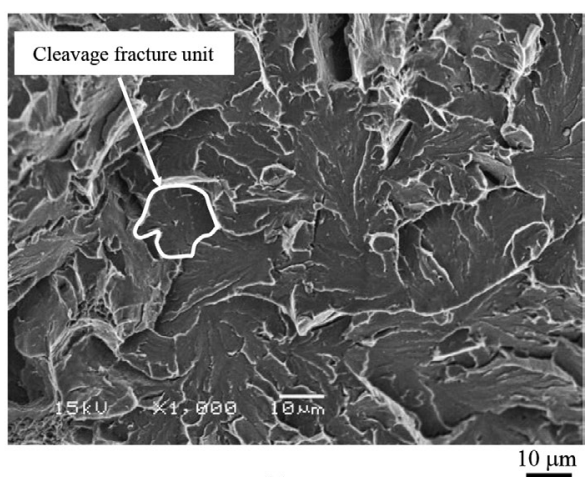

(b) Q-L-T

Fig. 7. SEM images of fracture surface broken at lower shelf energy temperature in Charpy test for Q-T (a) and Q-L-T (b) materials.

Table 3. CTOD properties used thin type specimen of Q-T and Q-L-T materials at $253 \mathrm{~K}$.

\begin{tabular}{c|c|c|c|c|c}
\hline & $\begin{array}{c}\text { Specimen } \\
\text { size }(\mathrm{mm})\end{array}$ & $\begin{array}{c}\text { T.P. } \\
\text { No. }\end{array}$ & Load $(\mathrm{kN})$ & $\begin{array}{c}\text { Notch opening } \\
\text { displacement V } \\
(\mathrm{mm})\end{array}$ & $\begin{array}{c}\text { CTOD } \\
\text { value } \delta \\
(\mathrm{mm})\end{array}$ \\
\hline \multirow{2}{*}{ Q-T } & \multirow{1}{*}{$\begin{array}{c}17.1 \times 34.2 \\
(\mathrm{~B} \times 2 \mathrm{~B})\end{array}$} & 1 & 31.2 & 0.51 & $0.09\left(\delta_{\mathrm{c}}\right)$ \\
\cline { 3 - 6 } & & 3 & 37.3 & 3.68 & $0.99\left(\delta_{\mathrm{m}}\right)$ \\
\hline \multirow{2}{*}{ Q-L-T } & $17.1 \times 34.2$ & 1 & 33.6 & 3.79 & $0.94\left(\delta_{\mathrm{m}}\right)$ \\
\cline { 3 - 6 } & $(\mathrm{B} \times 2 \mathrm{~B})$ & 2 & 32.8 & 3.95 & $0.96\left(\delta_{\mathrm{m}}\right)$ \\
\cline { 3 - 7 } & & 3 & 31.5 & 3.98 & $0.97\left(\delta_{\mathrm{m}}\right)$ \\
\hline
\end{tabular}

Table 4. CTOD properties used thick type specimen of Q-T and Q-L-T materials at $273 \mathrm{~K}$.

\begin{tabular}{c|c|c|c|c|c}
\hline & $\begin{array}{c}\text { Specimen } \\
\text { size }(\mathrm{mm})\end{array}$ & $\begin{array}{c}\text { T.P. } \\
\text { No. }\end{array}$ & Load $(\mathrm{kN})$ & $\begin{array}{c}\text { Notch opening } \\
\text { displacement V } \\
(\mathrm{mm})\end{array}$ & $\begin{array}{c}\text { CTOD } \\
\text { value } \delta \\
(\mathrm{mm})\end{array}$ \\
\hline Q-T & $\begin{array}{c}80 \times 80 \\
(\mathrm{~B} \times \mathrm{B})\end{array}$ & 1 & 387 & 2.68 & $0.59\left(\delta_{\mathrm{u}}\right)$ \\
\cline { 3 - 6 } Q-L-T & $\begin{array}{c}100 \times 100 \\
(\mathrm{~B} \times \mathrm{B})\end{array}$ & 1 & 373 & 1.83 & $0.38\left(\delta_{\mathrm{c}}\right)$ \\
\cline { 3 - 6 } & & 2 & 579 & 9.88 & $2.63\left(\delta_{\mathrm{m}}\right)$ \\
\hline
\end{tabular}


(塑性拘束効果) およびき裂先端に存在する破壊起点と成 り得る領域の体積 (体積効果) に起因することが知られて いる ${ }^{11)}$ 。また，塑性拘束効果と体積効果ともに試験片板厚 に依存するが, 試験片厚さ約 $10 \mathrm{~mm}$ を超えると体積効果が 支配的となる。本実験では，板厚 $10 \mathrm{~mm}$ 以上の試験片を用 いていることから，L処理による CTOD特性の向上は，破

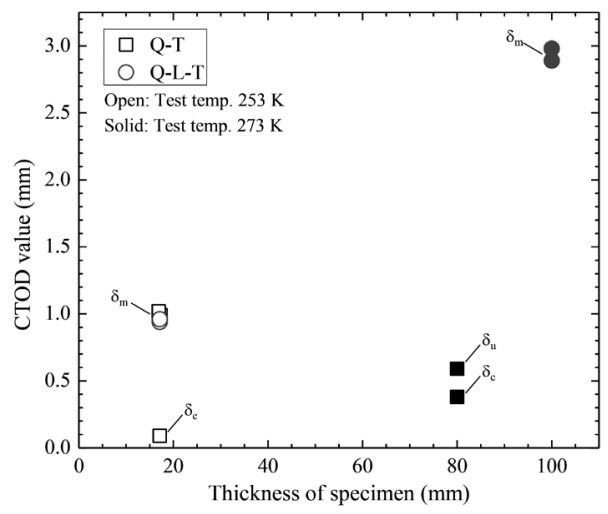

Fig. 9. Relationship between thickness of specimen and CTOD value at $253 \mathrm{~K}$ (Open) and $273 \mathrm{~K}$ (Solid) for Q-T and Q-L-T materials.
壊起点と成り得る領域が減少したためと考えられる。本結 果からも，シャルピー衝撃試験と同様に，L処理による低 温勒性の飛躍的な向上が認められた。

上述した結果より，本鋼種における機械的特性に及ぼす L処理の影響として, $0.2 \%$ Y.S. はやや低下するものの，低 温鞁性が飛躍的に向上することが明らかとなった。また， $\mathrm{L}$ 処理は海洋構造物用鋼などで要求される CTOD值などの 破壊靶性特性に対しても，安定的に，かつ良好な材料特性 を得るための調質方法と成り得ることが示された。

\section{$3 \cdot 2$ L処理によるミク口組織変化と析出物}

上述したように，光学顕微鏡を用いた組織観察結果で は，Q-T材と比較して，Q-L-T材の方が組織が複雑となっ た。この複雑さの詳細を確認するために，EBSD測定を 用いて，組織の詳細観察を実施した。Q-T材と Q-L-T材の Image Quality (IQ) マップをFig.10に，境界マップ（境界角 度 $\geqq 15^{\circ}$ ）をFig. 11 に示す。Q-T材と比較すると, Q-L-T材 では $15^{\circ}$ 以上の大角境界の蛇行打よび粒界・粒内に $15^{\circ}$ 以 上の大角境界を有する細粒が多く認められた。この組織の 形態変化が光学顕微鏡で認められる複雑さに起因したと 推察される。さらに, この形態変化は, L処理中の $\alpha \rightarrow \gamma の$ 逆変態挙動が 1 つ要因として挙げられる。そこで, 高温

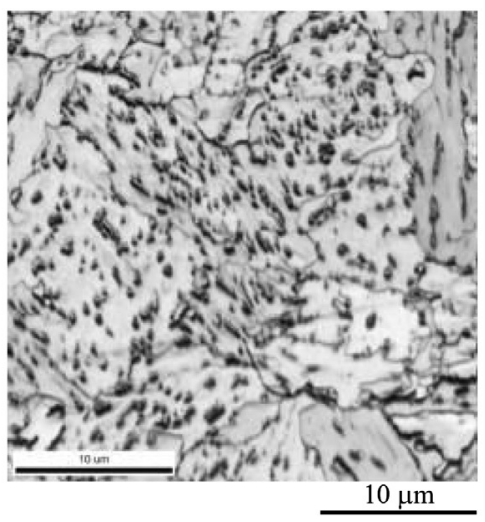

(b) Q-L-T

(a) Q-T

Fig. 10. Image quality maps of Q-T (a) and Q-L-T (b) materials measured by EBSD.

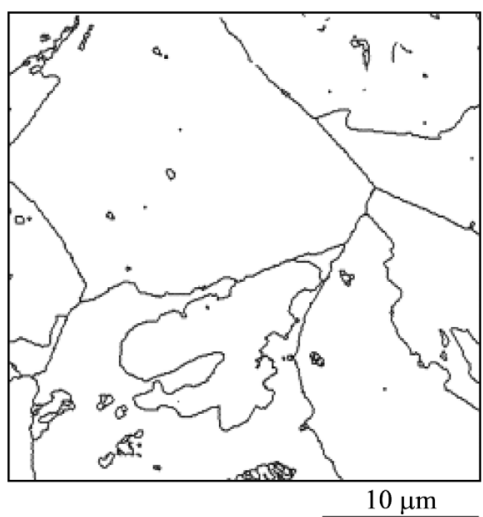

(a) Q-T

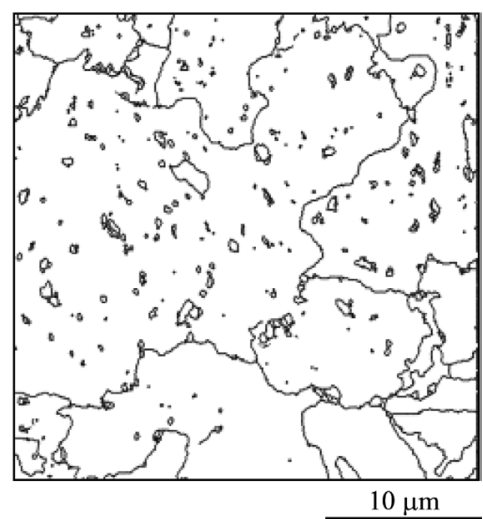

(b) Q-L-T

Fig. 11. EBSD grain boundary $\left(>15^{\circ}\right)$ map for Q-T and Q-L-T materials. 
$\mathrm{EBSD}$ を用い, $\mathrm{A}_{\mathrm{C} 1}$ 点以下から $\mathrm{A}_{\mathrm{C} 3}$ 点以上の各温度における 逆変態挙動を調査した。Phase mapを Fig.12に示す。加熱温 度が $903 \mathrm{~K}$ となると $\alpha$ 相の粒界から，わずかに逆変態 $\gamma$ が 生成していることがわかる。また，昇温に伴いその領域が 徐々に広がり, $1003 \mathrm{~K}$ では一部の粒内逆変態も進んできて いる。加熱温度が $1053 \mathrm{~K}$ まで上昇すると，未逆変態 $\alpha$ 領域 と逆変態 $\gamma$ 領域がかなり入り組んだ形で存在し, $\mathrm{A}_{\mathrm{C} 3}$ 点以 上の加熱温度 $1103 \mathrm{~K}$ では $\gamma$ 単相となった。温度と $\alpha$ 相およ び $\gamma$ 相の面積率の関係を Fig.13に示す。 $\mathrm{A}_{\mathrm{Cl}}$ 点近傍ではほと んど逆変態せず, 約 $950 \mathrm{~K}$ から徐々に逆変態 $\gamma$ 相が生成し 始め，約 $1050 \mathrm{~K}$ から $\mathrm{A}_{\mathrm{C} 3}$ 点に近づくにつれ， $\gamma$ 相の面積率 が急激に上昇した。本鋼種の変態点測定結果では $\mathrm{A}_{\mathrm{Cl}}$ 点が

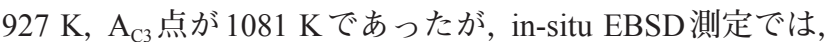

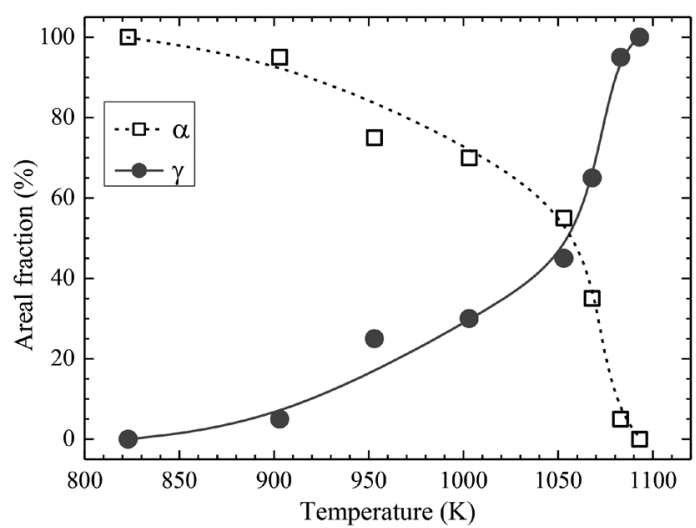

Fig. 13. Relationship between temperature and areal fraction of $\alpha$ and $\gamma$ phase.
$1083 \mathrm{~K}$ でも $\gamma$ 単相にならなかった。高温EBSDで得られた 変態温度が変態点測定から得られた変態温度 $\left(\mathrm{A}_{\mathrm{Cl}}\right.$ 点, $\mathrm{A}_{\mathrm{C}}$ 点）と異なる理由として，測定環境および測定範囲の違い が挙げられる。高温EBSD測定では高真空中で加熱してい るため, 極表層で脱炭や脱元素が生じる可能性があり，さ らに $80 \times 200 \mu \mathrm{m}$ というミク口な領域の変態挙動を観察し ている。一方で, 変態点測定は $\phi 3 \times L 10 \mathrm{~mm}$ の試験片全 体，即ちマクロな領域の熱膨張量から読み取る。この測定 領域のサイズの違いが, 変態点に差を生じさせた可能性が ある。また, $1003 \mathrm{~K}$ 以降に認められた粒内逆変態は昇温過 程で生じた炭化物および未固溶炭窒化物が起因している と考えられる。本鋼種のような $\alpha_{\mathrm{B}}$ を有する鋼種は，低Cで あっても島状マルテンサイト（M-A）が析出することが報 告されている ${ }^{12)}$ 。従って, 未固溶炭窒化物に加え, $\mathrm{L}$ 処理時 の昇温過程でM-Aの分解により生成した炭化物が粒内逆 変態の核生成サイトとなったと推論される。

本測定では局部から全体に広がる逆変態挙動を観察でき たものと考える。逆変態 $\gamma$ 相が未逆変態 $\alpha$ 相中に非常に入 り組んだ形で生成していることが確認され，これが Q-L-T 材で複雑な組織となった主因と考えられる。L処理中の $\alpha \rightarrow \gamma$ 逆変態には, 保持温度だけでなく保持時間も影響する ので ${ }^{13)}$ ，それについては今後の調査で明らかにしたい。

\section{$3 \cdot 3$ L処理による機械的特性発現メカニズムに関する考察}

上述したように, $\mathrm{Cu}$ 添加低合金鋼において L処理は以下 の特徵をもたらすことが分かった。

[1] Q-T材と同等レベルのT.S. を維持しながら $0.2 \% \mathrm{Y}$. S. が低下するため，結果的にYRが低下する。

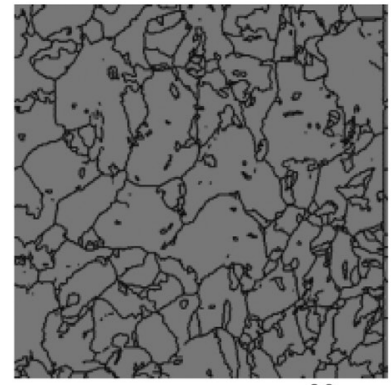

(a) at $823 \mathrm{~K} \quad \underline{30 \mu \mathrm{m}}$

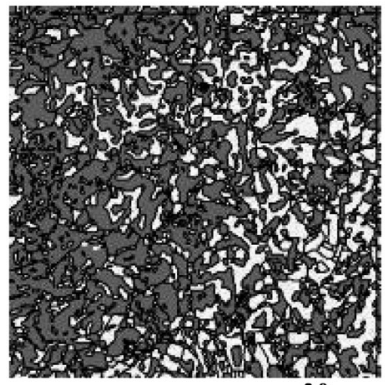

(d) at $1053 \mathrm{~K} 30 \mu \mathrm{m}$

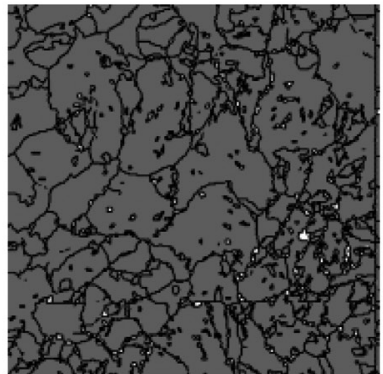

(b) at $903 \mathrm{~K} \quad 30 \mu \mathrm{m}$

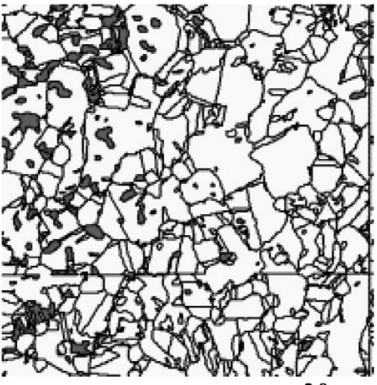

(e) at $1083 \mathrm{~K} \quad 30 \mu \mathrm{m}$

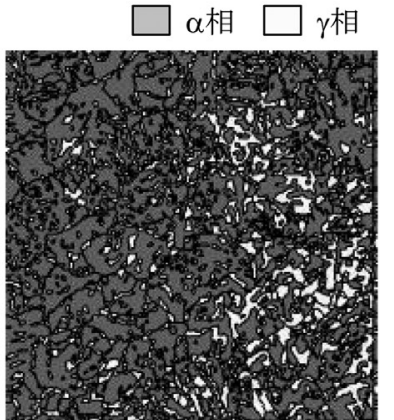

(c) at $1003 \mathrm{~K} \quad \underline{30 \mu \mathrm{m}}$

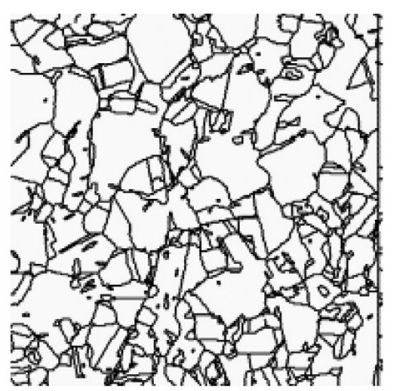

(f) at $1103 \mathrm{~K} \quad 30 \mu \mathrm{m}$

Fig. 12. Phase map of $\alpha$ and $\gamma$ phase measured by in-situ EBSD at $823 \mathrm{~K}$ (a), $903 \mathrm{~K}$ (b), $1003 \mathrm{~K}$ (c), $1053 \mathrm{~K}$ (d), $1083 \mathrm{~K}$ (e) and $1103 \mathrm{~K}$ (f). 
[2］著しいFATT の低下や CTOD值の増加が生じる（低温 䩡性が顕著に向上する)。

［1にについては，緒言で述べたように硬質相と軟質相の 共存が重要とされてきた。その観点から考察を試みる。ま ず, 未逆変態 $\alpha$ 相と逆変態 $\gamma$ 相の面積率および各相中の $\mathrm{Cu}$ の析出挙動について検討する。Fig.14にQ-Lまま材（L処理 温度 : $1053 \mathrm{~K}$, 保持時間 : $2 \mathrm{~h}$, 水冷材), Q まま材 (焼入れ 温度 : $1173 \mathrm{~K}$, 保持時間 : $1.5 \mathrm{~h}$, 水冷材) およびQ-T材 (焼 戻し温度： $873 \mathrm{~K}$, 保持時間 : $4 \mathrm{~h}$ ) の TEM観察結果を示す。 Qまま材では析出物がほぼ認めらなかったが，Q-T材では 粒内に多数の析出物が認められた。EDS 分析により，析出 物は $\mathrm{Cu}$ 析出物および $\mathrm{Nb}, \mathrm{Mo}$ 系の炭窒化物であることを 確認している。また, Q-Lまま材では, 粒界を挟んで析出物 のほほ存在しない領域 (右側) と析出物が凝集, 粗大化し ている領域 (左側) が認められた。この析出物も $\mathrm{Cu}$ 析出物 であることから，析出物の認められる領域は，未逆変態 $\alpha$ 相と考えられる。L処理は $1053 \mathrm{~K}$ 保持で T处理よりも高温 であり, $\mathrm{Cu}$ 析出物の凝集, 粗大化が進んだものと考えられ る。一方で, 析出物が認められない領域は逆変態 $\gamma$ 相と考 えられ, Qまま材と同様に, $\mathrm{L}$ 処理後の冷却過程でも $\mathrm{Cu}$ は 母相中に固溶したままと推定される。この逆変態 $\gamma$ 相中の 固溶 $\mathrm{Cu}$ はその後の焼戻し過程で析出し, 母相は時効硬化 する。すなわち, Q-L-T材においては, L 処理中の未逆変態 $\alpha$ 相は高温焼戻しを受け軟質相となり，逆変態 $\gamma$ 相は L 処理 後の焼戻し中に時効硬化し硬質相となるため, 軟質相と硬 質相の複合組織となる。この軟質相の存在が $0.2 \%$ Y.S. の低 下をもたらしたと考えられる。一方，Q-T材と Q-L-T材が ほぼ同じT.S.を示した理由として, Q-T材と Q-L-T材の加 工硬化特性の違いが考えられる。Fig.15にQ-T材と Q-L-T 材の応力ーひずみ曲線を示すが，Q-L-T材に顕著な加工硬 化が認められる。そこで，(2) 式のHollomonの式を用いて， 加工硬化係数を算出した。

$$
\sigma=F \cdot \varepsilon^{n}
$$

ここで, $\sigma$ は真応力, $\varepsilon$ は真ひずみ, $F$ は塑性係数, $n$ は加工 硬化指数である。Q-T材と Q-L-T材の $n$ 值は，それぞれ $n=$ $0.17, n=0.25$ となり, Q-L-T材の方が, 加工硬化能が高い。

この加工硬化挙動の違いは, 硬質相と軟質相の強度差抒 よび変形能の違いに起因すると考えられる。Sugimoto ら ${ }^{14)}$ は, ベイナイトを含む複合組織鋼を対象に, 強度と延性に ついて詳細に検討しており, 複合組織鋼の高い加工硬化率 はフェライトと第2相組織の強度差に起因して発生する 内部応力が原因としている。また, Kunishige ${ }^{15)}$ は連続 焼なまし型複合組織鋼（DP鋼）を対象に，加工硬化挙動を Ashby の理論 ${ }^{16)}$ を用いて詳細に検討しており, 加工硬化挙 動は第二相の量や粒径に支配されていると結論づけてい る。硬質相と軟質相の複雑な複合組織を形成する本鋼種の Q-L-T材に打いても，基本的には上述した挙動と類似の挙 動が起こった結果, Q-T材と同等のT.S. を示したと推論さ れる。

[2]については, 緒言で述べたように従来は残留 $\gamma$ の働 きが重要とされてきた。しかし, 本鋼種では残留 $\gamma$ は観察 されないので, 勒性に及ぼすミク口組織因子が他にあるは

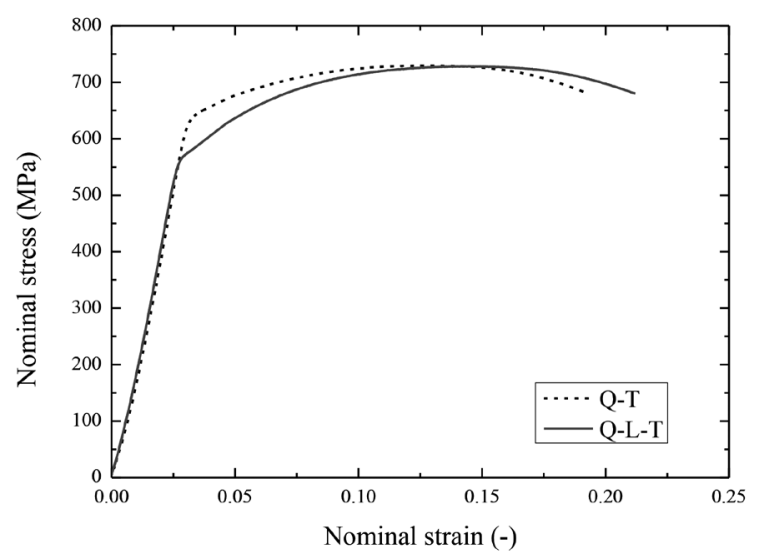

Fig. 15. Nominal stress-strain curves of Q-T and Q-L-T materials.

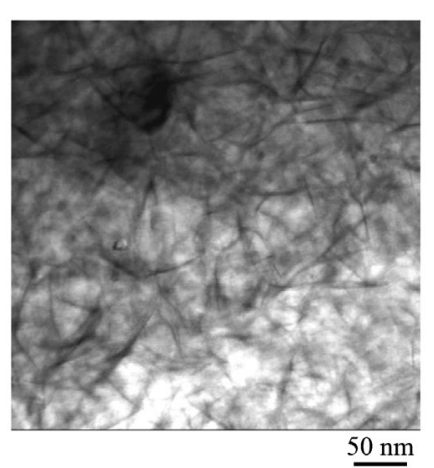

(a) As Q

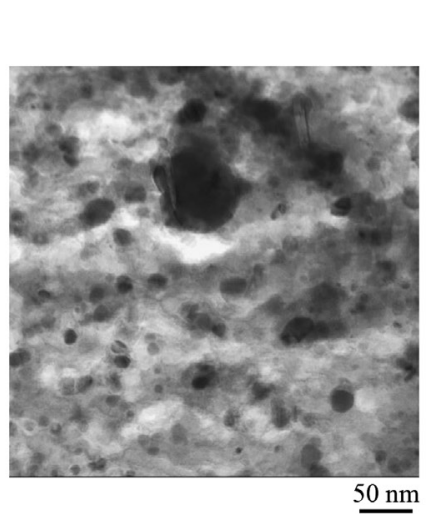

(b) Q-T

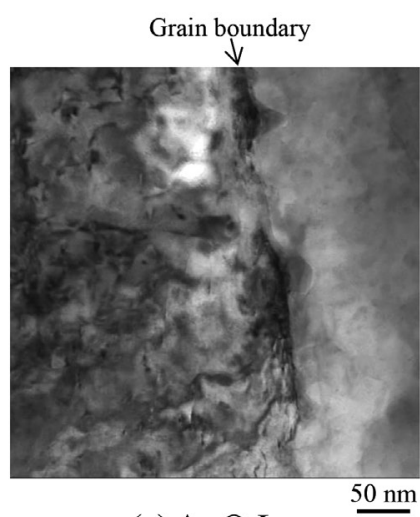

(c) As Q-L

Fig. 14. TEM images of As Q sample quenched from $1173 \mathrm{~K}$ (a), Q-T sample tempered at $873 \mathrm{~K}$ and As Q-L sample Lamellarized from $1053 \mathrm{~K}$. 
ずである。そこで， $d_{\mathrm{EFF}}$ を支配するミクロ組織の特定を試 みた。上述したように, Q-L-T材では $15^{\circ}$ 以上の大角境界 の蛇行と粒界打よび粒内に $15^{\circ}$ 以上の大角境界を有する細 粒が Q-T材と比べ多く認められている。本鋼種のような $\alpha_{\mathrm{B}}$ を有する鋼種に打いては, 大角境界がき裂進展の抵抗性を 有することが知られており ${ }^{17)}$, 粒界の蛇行や粒内の細粒が き裂進展の抵抗となる可能性がある。そこで，本鋼種のよ うな $\mathrm{Cu}$ 含有鋼であっても同様の傾向を示すのかを検証す るために, シャルピー衝撃試験片の破壊の起点部近傍に発 生したサブクラックに着目し，断面の EBSD測定を実施し た。Q-T材打よびQ-L-T材の大角境界マップを Fig.16に示 す。Q-T材, Q-L-T材ともにサブクラックは基本的には直 線的であるが，大角境界と交差するところで折机曲がりや 不連続点を発生している。また, Fig.16（a）に示したQ-T 材では，一つの粒内を直線的に横断するようなサブクラッ クが認められたが, Fig.16 (b) に示したQ-L-T材では, 粒 内に存在する大角境界を有する細粒によって，サブクラッ クが分断されており，穴の存在がき裂進展の抵抗性を有 していることが確認できる。以上の観察結果より, ベイニ
ティックフェライト粒径が勒性を基本的に左右している可 能性が高い。そこで, Q-T材およびQ-L-T材の $d_{\mathrm{EFF}}$ とべイニ ティックフェライト粒径の分布をFig.17に比較して示す。 参考として, 同図に旧 $\gamma$ 粒径の分布も示す。旧 $\gamma$ 粒径は $d_{\mathrm{EFF}}$ より全体的に粗大粒側に分布しており，一致しなかった。 一方で, ベイニティックフェライト粒径 (EBSD grain) は $d_{\mathrm{EFF}}$ と概ね一致することが確認された。ミクロ組織が $\alpha_{\mathrm{B}}$ 主 体の本鋼種は， $d_{\mathrm{EFF}}$ を支配するミクロ組織として, ベイニ ティックフェライト粒径が挙げられた。なお，この結果は Izumiyama ${ }^{17)}$ の結果と矛盾はなかった。ところで, Fig.17 (b) で示したQ-L-T材のベイニティックフェライト粒径の 分布に, 二つのピークが生じるのは興味深い。これは, L処 理中の逆変態打よび未逆変態領域の分布を示している可能 性があり, 今後 EBSD解析によってダブルピーク発生原因 を明らかにしたい。

上述した結果より, Q-L-T材は, Q-T材と比較してべイ ニティックフェライト粒径が細かく，さらに粒内にもき裂 進展の障壁となる大角境界を有する細粒が多いため, 勒性 の飛躍的な向上が認められたと推定される。Q-L-T材のべ

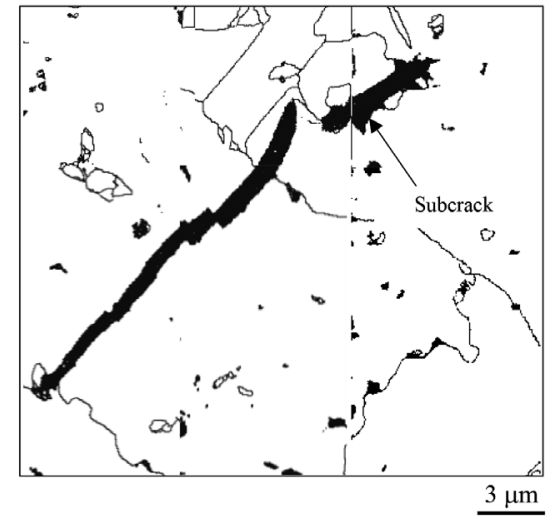

(a) Q-T

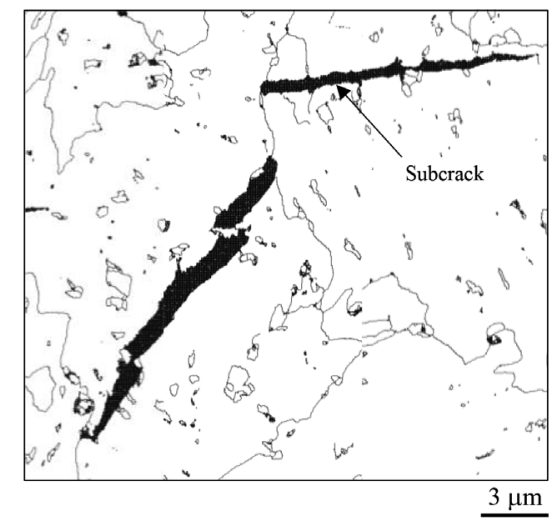

(b) Q-L-T

Fig. 16. Subcracks in the sample broken at lower shelf energy with EBSD grain boundary map for Q-T (a) and Q-L-T (b) materials.

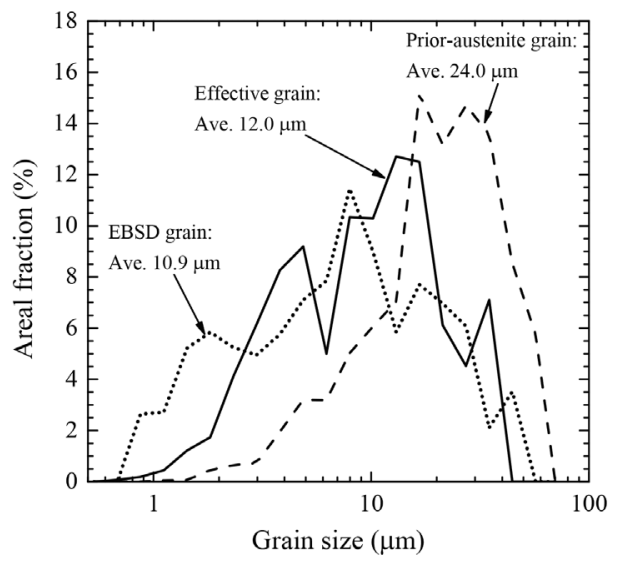

(a) Q-T

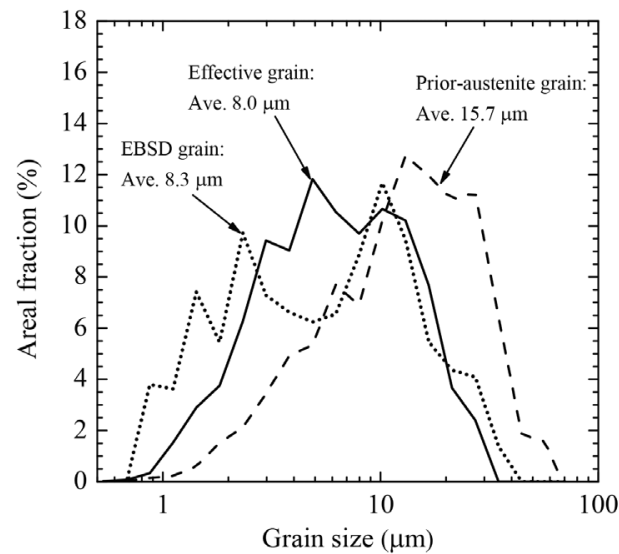

(b) Q-L-T

Fig. 17. Histograms of effective grain and EBSD grain (manifested by the boundaries with misorientation of 15 degrees or larger) and prior-austenite grain for the case with Q-T (a) and Q-L-T (b) materials. 
Table 5 Summary of experimental results for Q-T and Q-L-T materials.

\begin{tabular}{c|c|c|c|c|c|c|c|c|c}
\hline \multirow{2}{*}{ Sample } & \multirow{2}{*}{$\begin{array}{c}0.2 \% \mathrm{YS} \\
(\mathrm{MPa})\end{array}$} & \multirow{2}{*}{ TS $(\mathrm{MPa})$} & \multirow{2}{*}{ FATT $(\mathrm{K})$} & Prior austenite grain size $(\mu \mathrm{m})$ & \multicolumn{2}{|c|}{ EBSD grain $(\mathrm{mm})$} & \multicolumn{2}{c}{$d_{\text {EFF }}(\mu \mathrm{m})$} \\
\cline { 5 - 10 } & & & Maximum & Average & Maximum & Average & Maximum & Average \\
\hline Q-T & 640 & 729 & 233 & 68.3 & 24.0 & 52.0 & 10.9 & 41.5 & 12.0 \\
\hline Q-L-T & 569 & 726 & 193 & 55.6 & 15.7 & 41.3 & 8.3 & 31.7 & 8.0 \\
\hline
\end{tabular}

イニティックフェライト粒径の微細化は, 高温EBSD 測定 結果からも示されたように, $\alpha-\gamma$ の逆変態が部分的に, かつ 複雑に形成されていることに起因していることは容易に想 像できる。

Table 5 に本研究における実験結果をまとめた。L処理 によって生じる強度特性は, 未逆変態 $\alpha$ 相の軟質化により $0.2 \%$ Y.S. が低下する。一方で, T.S. が保持された理由とし て, 軟質相 (未逆変態 $\alpha$ 相) と硬質相 (逆変態 $\gamma$ 相) の分散 による強度不均一が要因となる加工硬化特性の変化が挙げ られる。鞀性の飛躍的な向上は, L処理中の部分的, かつ複 雑な $\alpha-\gamma$ の逆変態によるべイニティックフェライト粒径の 微細化および粒内の大角境界を有する細粒によるものと推 定される。L処理過程の逆変態 $\gamma$ 相中には C, Ni, Mnなどの 元素の濃化も発生すると報告されており ${ }^{18)}$, L処理による 機械的特性発現メカニズムを結論付けるためには, 元素の 再分配なども考慮したより詳細な検討が必要であるが，そ の端緒的な知見は得られたものと思われる。

\section{4. 結言}

$\mathrm{Cu}$ 添加低合金鋼を対象に, 機械的特性に及ぼす二相域焼 入れ $(\mathrm{L})$ の影響を明確にし，その特性発現メカニズムにつ いても組織形成挙動および析出物の詳細観察を基に考察し た。得られた結論を以下に示す。

(1) Q-T材, Q-L-T材ともにミクロ組織はグラニュラーベ イニティックフェライト $\left(\alpha_{\mathrm{B}}\right)$ の様相を呈した。また, Q-L-T材であっても, 残留 $\gamma$ は認められなかった。

（2）L処理の適用は，低温靶性を大幅に向上させた。また， その結果強度一靯性バランスが改善された。

（3）L処理により, 大角境界の蛇行および粒界・粒内に大 角境界を有する細粒が認められ, 複雑な組織が得られ た。この組織の複雑化は, $\mathrm{L}$ 処理中の $\alpha-\gamma$ の逆変態が非 常に複雑かつ部分的に起こる挙動に起因していると考 えられる。

(4) Q-L-T材では, Q-T材と同等レベルの T.S. を維持しなが ら $0.2 \%$ Y.S. が低下した。L処理による $0.2 \%$ Y.S.の低下
は, 未逆変態 $\alpha$ 相が高温焼戻しを受けて, 軟質相となる ことに起因していると考えられる。さらにT.S.につい ては, 逆変態した $\gamma$ 相が $\gamma \rightarrow \alpha$ 変態し, 焼戻されること により，硬質相としてふるまう。その結果，強度不均一 な組織となり, 内部応力による加工硬化特性の向上に 起因していると推論される。

（5）L処理による低温勒性の向上は，へき開破壊単位に対 応するべイニティックフェライトの微細化が主要因と 推定される。

\section{文献}

1 ) J.Saint-Marcoux and J.Legras: Offshore Technology Conf. 2014, OTC 2014, OTC, Houston, TX, 946(OTC-25165-MS).

2 ) M.A.Walsh and S.Price: Steel Forgings: Second Volume, STP1259, ASTM International, West Conshohocken, PA, (1997), 196.

3 ) K.Ueda, S.Endo and T.Ito: JFE Giho, 18(2007), 23.

4 ) N.Saitoh, R.Yamaba, H.Muraoka and O.Saeki: Shinnittetsu Giho, 348(1993), 25.

5 ) BS 7448-1: 1991, Fracture mechanics toughness tests. Method for determination of $\mathrm{K}_{\mathrm{IC}}$, critical CTOD and critical $\mathrm{J}$ values of metallic materials.

6 ) ISO 15653: 2010, Metallic materials -- Method of test for the determination of quasistatic fracture toughness of welds.

7 ) T.Araki: Netsu Shori (J. Jpn. Soc. Heat Treat.), 29(1989), 322.

8 ) T.Araki, M.Enomoto and K.Shibata: Tetsu-to-Hagané, 77(1991), 1544.

9 ) T.Hanamura, F.Yin and K.Nagai: ISIJ Int., 44(2004), 610.

10) T.Hanamura, M-C.Zhao, H.Qiu, F.Yin and K.Nagai: Tetsu-toHagané, 95(2009), 71.

11) F.Minami: J. Jpn. Weld. Soc., 75(2006) 416.

12) 鋼のベイナイト写真集 -1 , 日本鉄鋼協会基礎研究会ベイナイ 卜調査研究部会編，日本鉄鋼協会，東京，(1992), 156.

13) H.Kim, Y.Ahn, Y.Oh, G.Kim and J.Hong: 13th Int. Forgemasters Meeting, the Korean Institute of Metals and Materials, Seoul, Korea, (1997), 197.

14) K.Sugimoto, T.Sakaki, T.Kurihashi and O.Miyagawa: Tetsu-toHagané, 72(1986), 2101.

15) K.Kunishige, N.Nagao and M.Takahashi: Tetsu-to-Hagané, 68(1982), 1177.

16) M.F.Ashby: Philos. Mag., 14(1966), 1157.

17) Y.Izumiyama, R.Kayano and K.Nagai: Tetsu-to-Hagané, 100(2014), 704.

18) T.Tsuchiyama, S.Yamaguchi, G.Yamada, T.Inoue, T.Masumura and D.Akama: Netsu Shori, 56(2016), 221. 